IRSTI 34.45 .21

\author{
${ }^{1}$ P. Ramezannezhad, ${ }^{1 *}$ S. Heidari-Soureshjani, ${ }^{2}$ T. Suhan \\ ${ }^{1}$ Shahrekord University of Medical Sciences, Shahrekord, Iran \\ ${ }^{2}$ University of Michigan, Department of Pediatrics-Hematology/Oncology, Ann Arbor, MI, USA \\ *e-mail: heidari_62@yahoo.com
}

\title{
Protective effects of some medicinal plants against myocardial hypoxia
}

\begin{abstract}
Myocardial hypoxia is one of the main complications of myocardial ischemic injury which have high morbidity and mortality. The aim of this review is to investigate the protective effects of medicinal plants in myocardial hypoxia. The words cardiomyocytes alongside with hypox* or myocardial hypoxia, in combination with some herbal terms such as medicinal plant, phyto* and herb*, were used to search for relevant publications indexed in the Institute for Scientific Information (ISI) and PubMed. Finally after all revisions, 74 articles were included in this study. Available evidence shows that certain medicinal plants and herbal derivatives can exert their myocardial protective effects against hypoxia using several pathways. These mechanisms include antioxidant properties such as savaging reactive oxygen species (ROS) and activation antioxidant pathways, suppressing pro-apoptotic genes and regulate apoptosis pathways, regulating autophagy and related pathways, reducing inflammation and suppress proinflammatory cytokines and pathways, inhibiting intracellular $\mathrm{Ca}^{2+}$ influx, antiplatelet aggregation, stimulating the adenosine triphosphate (ATP) generation in mitochondria and mitochondrial respiration, promoting autophagy, regulating hypoxia-inducible factor 1-alpha (HIF-1 $\alpha$ ) expression, decreasing the expression of angiotensin, reducing cardiac troponin I (cTnI) and creatine kinase-MB (CK-MB) and up-regulation of epoxyeicosatrienoic acids (EETs). Thus, clinicians can use the medicinal herbs as an effective treatment against myocardial hypoxia. Post-ischemia and chronic treatment of cardioprotection maybe consider as a therapeutic strategies than short term and pre-treatment methods in clinical setting. Nevertheless, more clinical trial studies are required in order to obtain more reliable results.
\end{abstract}

Key words: antihypoxic, medicinal plants, reactive oxygen species, myocardial ischemic injury.

\section{Introduction}

Myocardial ischemic injury occurs due to severe dysfunction of coronary blood supply and is a leading cause of morbidity and mortality worldwide [1]. This disorder is closely associated with cardiac dysfunction, in particular some aspects of it, such as myocardial stunning, left ventricular remolding, inflammation, fibrosis, neurohormonal activation, cardiomyocyte necrosis, reperfusion injury, haemorhage and microvascular obstraction are causes heart failure [2]. Myocardial ischemic injury is a pathological process that includes augmented cell death, namely, oncosis, apoptosis and infarction [3]. Cardiomyocytes consume large quantities of energy and are very sensitive to lack of energy. During heart attack and eventually hypoxia, cardiac myocytes switch their metabolism to anaerobic respiration, which causes ATP depletion, lactate accumulation, $\mathrm{Na}^{+}$and $\mathrm{Ca}^{2+}$ overload and due to myocardial contractile dysfunction. Reperfusion results in generation of reactive oxygen species (ROS), what contributes to apoptosis and inflammation and finally myocardial infarction and ischemic reperfusion injury [4].

Currently there are several therapeutic strategies used for treatment, not as effective as could be [4]. As a result, new investigations are considered necessary in this area. Medicinal plants are the cheapest and conventional approach to confronting numerous diseases especially for treatment of heart failure [5-13]. Given that the magnitude of heart disease in human mortality and necessity for new therapeutic strategies to treatment of chronic heart failure are high, this review was prepared to find out the protective effects of medicinal plants in myocardial hypoxic condition and its related complications. 


\section{Search for strategies and study design}

Key words of interest, such as cardiomyocytes alongside with hypox* or myocardial hypoxia, in combination with some herbal terms, namely medicinal plant, phyto*, and herb* were used to search for relevant publications indexed in the Institute for Scientific Information (ISI) and PubMed. Finally, 74 articles were found with Endnote software (Table 1).

Table 1 - Number of studies present in subsequent databases

\begin{tabular}{|l|c|c|}
\hline \multirow{2}{*}{$\begin{array}{l}\text { Hypox* }+ \text { Cardiomyocyte }+ \text { Medicinal } \\
\text { plant }\end{array}$} & PubMed & 3 \\
\cline { 2 - 3 } Hypox* + Cardiomyocyte + Phyto* & ISI & 1 \\
\cline { 2 - 3 } & PubMed & 3 \\
\hline \multirow{2}{*}{ Hypox* + Cardiomyocyte + Herb* } & ISI & 1 \\
\cline { 2 - 3 } & PubMed & 22 \\
\hline \multirow{2}{*}{ Myocardial hypoxia + Medicinal plant } & PubMed & 19 \\
\cline { 2 - 3 } & ISI & 6 \\
\hline \multirow{2}{*}{ Myocardial hypoxia + Phyto* } & PubMed & 9 \\
\cline { 2 - 3 } & ISI & 9 \\
\hline \multirow{2}{*}{ Myocardial hypoxia + Herb* } & PubMed & 68 \\
\cline { 2 - 3 } & ISI & 46 \\
\hline \multirow{2}{*}{ Total } & PubMed & 120 \\
\cline { 2 - 3 } & ISI & 82 \\
\hline
\end{tabular}

A standard form, which included items as purpose or the title of the study, intervention, outcome, variables, journal name, intervention period, and article number, was designed. Selection process is presented on Figure 1.

First, full text articles relevant to the purpose of the study were recorded in the form and entered into the study with agreement of researchers. Then, the plants and their products that were reported to be effective to treat myocardial hypoxia and related complications were selected for the study. Articles, where full texts were not accessible, non-English language articles, studies with non-positive effects, review articles, and studies that were not relevant to the principle aim of the current study were excluded after all authors' agreement was achieved. Finally, 74 articles were included into the study.

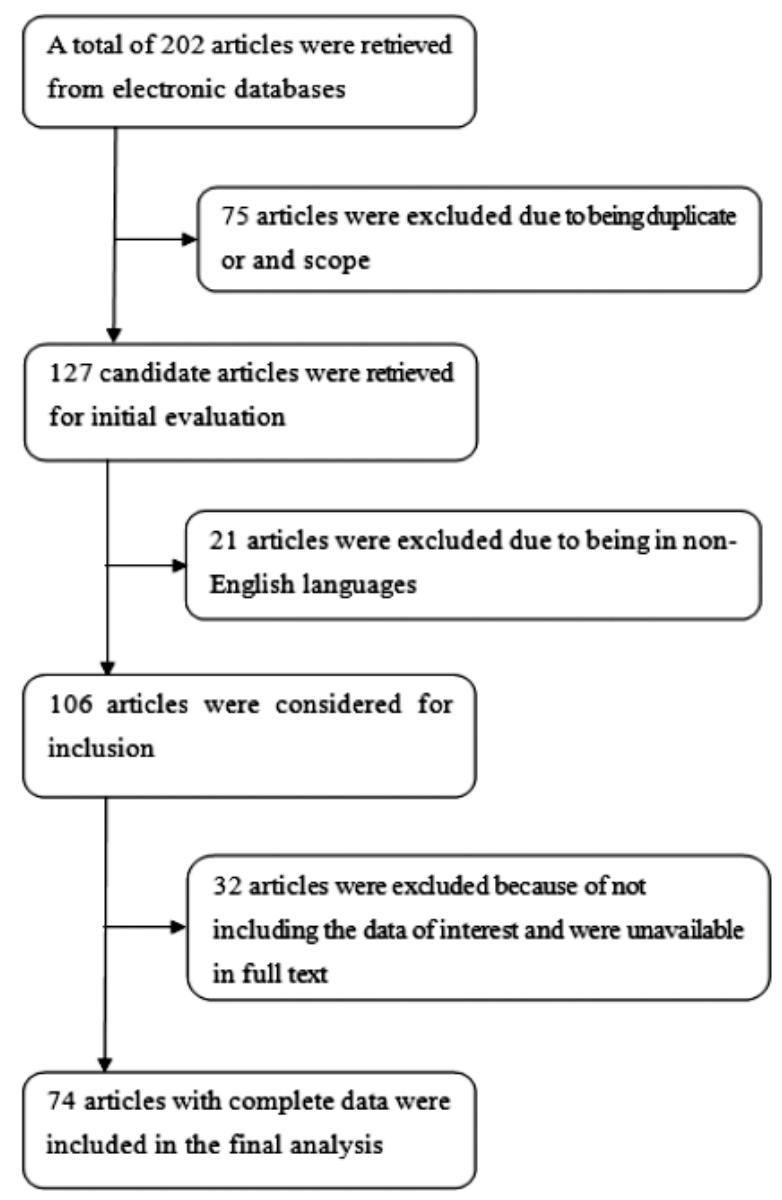

Figure 1 - The process of selection of articles for final analysis.

\section{Results and discussion}

Medicinal plants and their compounds can be effective against myocardial hypoxia via various mechanisms of action. Summary of analysis for some of them is provided in Table 2. 
Table 2 - Medicinal plants, formula and compounds with cardioprotective effects and mechanisms of action against myocardial hypoxia

\begin{tabular}{|c|c|c|c|c|}
\hline \multicolumn{5}{|c|}{ Medicinal plants } \\
\hline $\begin{array}{l}\text { Refe- } \\
\text { rences }\end{array}$ & Main effects or mechanisms & $\begin{array}{c}\text { Type of } \\
\text { administration }\end{array}$ & Study design & Scientific name of the plant \\
\hline$[14]$ & $\begin{array}{l}\text { Diminishing levels of oxidants generated } \\
\text { during hypoxia and within exposure to the } \\
\text { mitochondrial site III inhibitor antimycin A } \\
\text { and decreasing cell death }\end{array}$ & Aqueous extract & $\begin{array}{l}\text { Experimental } \\
\text { (in vitro) }\end{array}$ & Scutellaria baicalensis Georgi \\
\hline$[15]$ & $\begin{array}{l}\text { Reducing degenerative intra mitochondrial } \\
\text { areas. In addition insert protective effect } \\
\text { to reducing number of ATPase particles at } \\
\text { the inner mitochondrial membranes and } \\
\text { increasing of myocardial capacity for ATP } \\
\text { production }\end{array}$ & Extract & $\begin{array}{l}\text { Experimental } \\
\text { (in vitro and } \\
\text { in vivo) }\end{array}$ & Ginkgo biloba \\
\hline$[16]$ & $\begin{array}{l}\text { Increasing the expressions of hypoxia- } \\
\text { inducible factor 1alpha (HIF-1alpha), } \\
\text { hypoxia-inducible factor 1beta (HIF-1beta) } \\
\text { and vascular endothelial growth factor } \\
\text { (VEGF) mRNAs and the expressions of HIF- } \\
\text { lalpha and VEGF proteins }\end{array}$ & Solution & $\begin{array}{l}\text { Experimental } \\
\text { (in vitro and } \\
\text { in vivo) }\end{array}$ & Radix et rhizoma Rhodiolae kirilowii \\
\hline$[17]$ & $\begin{array}{l}\text { Decreasing }\left[\mathrm{Ca}\left({ }^{2+}\right)\right] \text { i contents in cardiac } \\
\text { muscel cells and inhibiting the changes } \\
\text { induced by Potassium chloride }(\mathrm{KCl}) \text { in } \\
\text { single cardiac myocytes }\end{array}$ & Powder extract & $\begin{array}{l}\text { Experimental } \\
\text { (in vitro) }\end{array}$ & Rhododendron dauricum $L$. \\
\hline [18] & $\begin{array}{l}\text { Decreasing the level of MDA, intracellular } \\
\text { ROS, release of LDH and apoptosis. Besides } \\
\text { enhancement the activity of SOD }\end{array}$ & $\begin{array}{l}\text { Aqueous and } \\
\text { ethanolic extract }\end{array}$ & $\begin{array}{l}\text { Experimental } \\
\text { (in vitro) }\end{array}$ & Pseudostellaria heterophylla \\
\hline [19] & $\begin{array}{l}\text { Increasing mitochondrial ATP-generation } \\
\text { capacity (ATP-GC) and ADP-stimulating } \\
\text { state } 3 \text { respirations and increasing antioxidant } \\
\text { capacity. In addition enhancement of cellular } \\
\text { glutathione redox cycling and reducing } \\
\text { apoptosis }\end{array}$ & Dried extract & Ex-vivo & $\begin{array}{l}\text { Cistanche } \\
\text { deserticola }\end{array}$ \\
\hline [20] & $\begin{array}{l}\text { Protected myocyte cells against hypoxia via } \\
\text { ROS scavenger }\end{array}$ & Aqueous extract & $\begin{array}{l}\text { Experimental } \\
\text { (in vitro) }\end{array}$ & Pogostemon cablin Blanco \\
\hline [21] & $\begin{array}{l}\text { Reducing apoptosis and oxidative stress via } \\
\text { activation of PI3 K/Akt signaling pathway }\end{array}$ & Aqueous extract & $\begin{array}{l}\text { Experimental } \\
\text { (in vitro) }\end{array}$ & $\begin{array}{l}\text { Dictamnus } \\
\text { dasycarpus Turcz }\end{array}$ \\
\hline [22] & $\begin{array}{l}\text { Reducing calcium accumulation, inhibiting } \\
\text { caspase-3 activation, and down-regulating } \\
\text { protein expression of p-JNK and p-p38MAPK }\end{array}$ & Extract & $\begin{array}{l}\text { Experimental } \\
\text { (in vitro and } \\
\text { in vivo) }\end{array}$ & Trichosanthes cucumerina \\
\hline \multicolumn{5}{|c|}{ Medicinal plants formula } \\
\hline $\begin{array}{c}\text { Refer- } \\
\text { ences }\end{array}$ & Main effects or mechanisms & \begin{tabular}{c|c|} 
Type of \\
administration \\
\end{tabular} & Study design & $\begin{array}{l}\text { Herbal compounds/ } \\
\text { derivatives }\end{array}$ \\
\hline [23] & $\begin{array}{l}\text { Inhibited reduced GSH and also a reduced } \\
\text { sensitivity to } \mathrm{Ca}^{2+} \text {-induced mitochondrial } \\
\text { permeability transition. In addition activated } \\
\text { both ERK/Nrf2 and PKC epsilon/m ATP- } \\
\text { sensitive potassium channel (K-ATP) pathways }\end{array}$ & Decoction & $\begin{array}{l}\text { Experimental } \\
\text { (in vitro) }\end{array}$ & $\begin{array}{l}\text { Danshen and Gegen composed of } \\
\text { Salviae miltiorrhizae and Puerariae } \\
\text { lobatae }\end{array}$ \\
\hline [24] & $\begin{array}{l}\text { Decreasing calcium accumulation and reducing } \\
\text { cell apoptosis by protecting cell membrane } \\
\text { skeleton integrity and the mitochondrial } \\
\text { function. }\end{array}$ & Decoction & $\begin{array}{l}\text { Experimental } \\
\text { (in vitro) }\end{array}$ & Danshen and Gegen \\
\hline
\end{tabular}


Continuation of table 2

\begin{tabular}{|c|c|c|c|c|}
\hline$[25]$ & $\begin{array}{l}\text { Up-regulation of epoxyeicosatrienoic acids } \\
\text { (EETs)-generating cytochrome P450 enzymes }\end{array}$ & Extracted Pill & $\begin{array}{l}\text { Experimental } \\
\text { (in vitro and } \\
\text { in vivo) }\end{array}$ & $\begin{array}{l}\text { Danshen composed of Salviae } \\
\text { Miltiorrhizae, Notoginseng Radix and } \\
\text { Borneolum Syntheticum }\end{array}$ \\
\hline$[26]$ & $\begin{array}{l}\text { enhancing antioxidant capacity and calcium } \\
\text { handling and lead to reducing apoptosis rates }\end{array}$ & Solution & $\begin{array}{l}\text { Experimental } \\
\text { (in vitro) }\end{array}$ & $\begin{array}{l}\text { Danshen composed of Salviae } \\
\text { Miltiorrhizae, Notoginseng Radix and } \\
\text { Borneolum Syntheticum }\end{array}$ \\
\hline$[27]$ & $\begin{array}{l}\text { Promoting autophagy via activation of the } \\
\text { mitogen activated protein kinase/ERK pathway }\end{array}$ & Solution & $\begin{array}{l}\text { Experimental } \\
\text { (in vitro) }\end{array}$ & $\begin{array}{l}\text { Tongxinluo composed of Radix } \\
\text { ginseng, Hirudo, Eupolyphaga } \\
\text { seusteleophaga, Buthus martensi, } \\
\text { Scolopendra subspinipes, Periostracum } \\
\text { cicadae, Semen ziziphi spinosae, Radix } \\
\text { paeoniae rubra, Lignum santali albi, } \\
\text { Lignum dalbergiae odoriferae, and } \\
\text { Borneolum syntheticum }\end{array}$ \\
\hline$[28]$ & $\begin{array}{l}\text { Up-regulating proteins which involving } \\
\text { in regulation of metabolic process, cell } \\
\text { proliferation and stress response. }\end{array}$ & Solution & $\begin{array}{l}\text { Experimental } \\
\text { (in vitro) }\end{array}$ & Tongxinluo \\
\hline$[29]$ & $\begin{array}{l}\text { Activating Angptl4-mediated regulation } \\
\text { of endothelial barrier integrity through the } \\
\text { PPAR- } \alpha \text { pathway }\end{array}$ & Solution & $\begin{array}{l}\text { Experimental } \\
\text { (in vitro and } \\
\text { in vivo) }\end{array}$ & Tongxinluo \\
\hline$[30]$ & $\begin{array}{l}\text { Increasing cell viability and SOD levels and } \\
\text { decreased MDA levels. Besides suppressing } \\
\text { MDA, cTnT and inflammatory cytokines. }\end{array}$ & Extract capsule & $\begin{array}{l}\text { Experimental } \\
\text { (in vitro and } \\
\text { in vivo) }\end{array}$ & $\begin{array}{l}\text { Yindanxinnaotong composed of } \\
\text { Ginkgo biloba, Salvia miltiorrhizae, } \\
\text { Gynostemma, ynostemmatis, } \\
\text { Erigerontis herba, Allii sativi } \\
\text { bulbus, Radix/rhizoma notoginseng, } \\
\text { Crataegi fructus and Borneolum }\end{array}$ \\
\hline$[31]$ & $\begin{array}{l}\text { Inhibition of mitochondrial permeability } \\
\text { transition pore (mPTP) opening via attenuating } \\
\mathrm{Ca}^{2+} \text { overload and ROS generation }\end{array}$ & Extract & $\begin{array}{l}\text { Experimental } \\
\text { (in vitro) }\end{array}$ & $\begin{array}{l}\text { Danhong composed of Salvia } \\
\text { miltiorrhiza Bge and Carthamus } \\
\text { tinctorius L. }\end{array}$ \\
\hline$[32]$ & $\begin{array}{l}\text { Reducing in MDA, LDH, cardiac troponin } \\
\text { I (cTnI) and creatine kinase-MB (CK-MB) } \\
\text { and reducing expression of cleaved caspase-3, } \\
\text { 8-hydroxydeoxyguanosine (8-OHdG), and } \\
\text { increasing SOD activity, Bcl-2/Bax ratio and } \\
\text { regulating Akt/Nrf2/HO-1 signaling }\end{array}$ & Solution & $\begin{array}{l}\text { Experimental } \\
\text { (in vitro and } \\
\text { in vivo) }\end{array}$ & $\begin{array}{l}\text { Danhong injection composed of Salvia } \\
\text { miltiorrhiza and Carthamus tinctorius } \\
\text { L+ hydroxysafflor yellow A that are the } \\
\text { main active ingredients of Radix Salvia } \\
\text { miltiorrhiza }\end{array}$ \\
\hline$[33]$ & $\begin{array}{l}\text { Inhibiting myocardial apoptosis, probably by } \\
\text { regulating hypoxia-inducible factor 1-alpha } \\
\text { (HIF-1 } \alpha \text { ) expression in cardiomyocytes }\end{array}$ & Extract Pill & $\begin{array}{l}\text { Experimental } \\
\text { (in vitro and } \\
\text { in vivo) }\end{array}$ & $\begin{array}{l}\text { Qishen Yiqi Droping Pill composed } \\
\text { of Salvia miltiorrhiza Bge, Pannax } \\
\text { notoginseng, and Dalbergia odorifera } \\
\text { T. Chen. }\end{array}$ \\
\hline$[34]$ & $\begin{array}{l}\text { Reducing inflammation of the endothelial } \\
\text { cells, inhibiting the activity of LDH, CK and } \\
\text { decreasing the level of MDA and increasing } \\
\text { SOD activity }\end{array}$ & Extract & $\begin{array}{l}\text { Experimental } \\
\text { (in vivo) }\end{array}$ & $\begin{array}{l}\text { Yi-Qi-Fu-Mai composed of Panax } \\
\text { ginseng, Ophiopogon japonicas and } \\
\text { Schisandra chinensis }\end{array}$ \\
\hline$[13]$ & $\begin{array}{l}\text { Inhibiting mitochondrial mediated apoptosis } \\
\text { and modulating AMP-activated protein kinase } \\
\text { (AMPK) activation mediating mitochondrial } \\
\text { fission }\end{array}$ & Powder & $\begin{array}{l}\text { Experimental } \\
\text { (in vitro and } \\
\text { in vivo) }\end{array}$ & Yi-Qi-Fu-Mai \\
\hline$[35]$ & $\begin{array}{l}\text { Reducing }\left[\mathrm{Ca}^{(2+)}\right] \text { i accumulation induced by } \\
\text { hypoxia-reoxygenation in ventricular myocytes } \\
\text { via supressing } \mathrm{I}_{\mathrm{NaL}} \text { and } \mathrm{I}_{\mathrm{CaL}}\end{array}$ & Extract & $\begin{array}{l}\text { Experimental } \\
\text { (in vitro) }\end{array}$ & $\begin{array}{l}\text { Wenxin Keli composed of Nardostachys } \\
\text { chinensis Batal, Codonopsis, } \\
\text { Notoginseng, amber, and Polygonati }\end{array}$ \\
\hline
\end{tabular}




\begin{tabular}{|c|c|c|c|c|}
\hline [36] & $\begin{array}{l}\text { Inhibiting autophagy through regulating } \\
\text { AMPK-mTOR signaling pathways and } \\
\text { increasing cell viability and consequently } \\
\text { reduced apoptosis. }\end{array}$ & Decoction & $\begin{array}{l}\text { Experimental } \\
\text { (in vitro) }\end{array}$ & $\begin{array}{l}\text { XuefuZhuyu decoction composed of } \\
\text { Angelica sinensis (Oliv.) Diels Rehman- } \\
\text { nia glutinosa Libosch Prunu persica } \\
\text { (L.), Batsch, Carthamus tinctorius L., } \\
\text { Paeonia Lactiflora Pall. Bupleurum } \\
\text { chinense DC, Citrus aurantium L., } \\
\text { Glycyrrhiza uralensis Fisch., Platy- } \\
\text { codon grandiflorum (Jacq.) A.DC. } \\
\text { Ligusticum chuanxiong Hort. and Achy- } \\
\text { ranthes bidentata Blume }\end{array}$ \\
\hline [37] & $\begin{array}{l}\text { Increasing cardiomyocytes survival by } \\
\text { regulating stress-responsive mitogen-activated } \\
\text { protein kinases (MAPK) pathways and } \\
\text { phosphatidylinositol 3-kinase (PI3K)-Akt } \\
\text { pathway for cell survival was restored by the } \\
\text { herbal compounds }\end{array}$ & Solution & $\begin{array}{l}\text { Experimental } \\
\text { (in vitro) }\end{array}$ & $\begin{array}{l}\text { Tanshinone IIA from Salvia miltiorrhiza } \\
\text { Bunge and astragaloside IV from } \\
\text { Astragalus membranaceus }\end{array}$ \\
\hline [38] & $\begin{array}{l}\text { Decreasing myocardium infarct size, reducing } \\
\text { apoptosis and myocardial myeloperoxidase } \\
\text { (MPO). In addition decreasing MDA, calcium } \\
\text { accumulation, LDH, creatine kinase MB } \\
\text { isoenzyme (CK-MB), and cardiac troponin I } \\
\text { (cTn-I) activity }\end{array}$ & Solution & $\begin{array}{l}\text { Experimental } \\
\text { (in vitro and } \\
\text { in vivo) }\end{array}$ & $\begin{array}{l}\text { Sheng-Mai-San composed of } \\
\text { ginsenoside Rb1 (ginsenosides of } \\
\text { Panax ginseng), ruscogenin, } \\
\text { (saponins of radix ophiopogonis) } \\
\text { and schisandrin (lignans of Fructus } \\
\text { schisandrae) }\end{array}$ \\
\hline [39] & $\begin{array}{l}\text { Activating of Peroxisome proliferator activated } \\
\text { receptor gamma co-activator (PGC-1 } \alpha \text { ) and } \\
\text { maintenance of mitochondrial functions } \\
\text { via involving the activation of AMPK } \\
\text { phosphorylation }\end{array}$ & Decoction & $\begin{array}{l}\text { Experimental } \\
\text { (in vitro and } \\
\text { in vivo) }\end{array}$ & $\begin{array}{l}\text { Yiqihuoxue Astragalus } \\
\text { membranaceus, Angelica sinensis, } \\
\text { Panax ginseng, Ligusticum wallichii, } \\
\text { and Panax notoginseng }\end{array}$ \\
\hline [40] & $\begin{array}{l}\text { Regulating of } \mathrm{Ca}^{2+} \text { influx, reducing oxidative } \\
\text { stress and apoptotic proteins (Mainly by Salvia } \\
\text { miltiorrhiza Bunge) }\end{array}$ & Aqueous extract & $\begin{array}{l}\text { Experimental } \\
\text { (in vitro) }\end{array}$ & $\begin{array}{l}\text { Xin-Ke-Shu that composed of Salvia } \\
\text { miltiorrhiza Bge, Pueraria lobata, } \\
\text { Ohwi, Panax notoginseng F.H. } \\
\text { Chen., Crataegus pinnatifida Bunge and } \\
\text { Aucklandia lappa Decne }\end{array}$ \\
\hline [41] & $\begin{array}{l}\text { Promoting mitochondrial function through } \\
\text { increasing respiration, ATP-coupled respiration, } \\
\text { and spare capacity of mitochondria in response } \\
\text { to hypoxia }\end{array}$ & Solution & $\begin{array}{l}\text { Experimental } \\
\text { (in vitro and } \\
\text { in vivo) }\end{array}$ & $\begin{array}{l}\text { Shenmai formula composed of } \\
\text { Panax ginseng and Ophiopogonis }\end{array}$ \\
\hline [42] & $\begin{array}{l}\text { Activating RISK pathway and reducing } \\
\text { apoptosis. In addition insert cardioprotective } \\
\text { effects by antioxidant activity }\end{array}$ & Decoction & $\begin{array}{l}\text { Experimental } \\
\text { (in vitro) }\end{array}$ & $\begin{array}{l}\text { Gualou Xiebai composed of } \\
\text { Trichosanthis Fructus and } \\
\text { Allii Macrostemonis Bulbus }\end{array}$ \\
\hline \multicolumn{5}{|c|}{ Medicinal plants compounds } \\
\hline $\begin{array}{l}\text { Refer- } \\
\text { ences }\end{array}$ & Main effects or mechanisms & $\begin{array}{c}\text { Type of } \\
\text { administration }\end{array}$ & Study Design & $\begin{array}{c}\text { Herbal compounds/ } \\
\text { derivatives }\end{array}$ \\
\hline [43] & $\begin{array}{l}\text { Improving hypoxic contractile recovery. Main } \\
\text { mechanism associated with restoration of tissue } \\
\text { ionic concentrations and reducing the release of } \\
\text { ATP metabolites and creatine kinase from the } \\
\text { hypoxic hearts }\end{array}$ & Solution & $\begin{array}{l}\text { Experimental } \\
\text { (in vivo) }\end{array}$ & $\begin{array}{l}\text { Tanshinone VI derived from } \\
\text { Salvia miltiorrhiza Bunge }\end{array}$ \\
\hline [44] & $\begin{array}{l}\text { Reducing infarct size and preventing the } \\
\text { increase in superoxide dismutase-mRNA and } \\
\text { inhibition of } 45 \mathrm{Ca}^{2+} \text { influx }\end{array}$ & Solution & $\begin{array}{l}\text { Experimental } \\
\text { (in vivo) }\end{array}$ & $\begin{array}{l}\text { Trilinolein derived from } \\
\text { Panax pseudoginseng }\end{array}$ \\
\hline [45] & $\begin{array}{l}\text { Increasing in } \mathrm{Cu} . \mathrm{Zn} \text {-superoxide dismutase } \\
\text { (SOD) activity and indicating antioxidant effect } \\
\text { that insert its myocardial protective effect }\end{array}$ & Solution & $\begin{array}{l}\text { Experimental } \\
\text { (in vivo) }\end{array}$ & $\begin{array}{l}\text { Trilinolein derived from } \\
\text { Panax pseudoginseng }\end{array}$ \\
\hline
\end{tabular}


Continuation of table 2

\begin{tabular}{|c|c|c|c|c|}
\hline [46] & $\begin{array}{l}\text { Augmenting the force recovery from } \\
\text { reperfusion and arrhythmia via decreasing }[\mathrm{Cl}-] \\
\mathrm{i} \text { in non-hypoxic myocytes and modulation of } \\
\text { intracellular Cl- homeostasis }\end{array}$ & Extract & $\begin{array}{l}\text { Experimental } \\
\text { (in vitro and } \\
\text { in vivo) }\end{array}$ & $\begin{array}{l}\text { Sasanquasaponin derived } \\
\text { from Camellia oleifera }\end{array}$ \\
\hline [47] & $\begin{array}{l}\text { Decreasing lactate dehydrogenase (LDH) } \\
\text { release, malondialdehyde, oxidized glutathione } \\
\text { (GSSG) contents and reactive oxygen species } \\
\text { (ROS) levels. In addition increasing activities } \\
\text { of Glutathione (GSH) contents and superoxide } \\
\text { dismutase, catalase and glutathione peroxidase. } \\
\text { Besides reducing calcium accumulation in } \\
\text { cardiomyocytes. }\end{array}$ & Extract & $\begin{array}{l}\text { Experimental } \\
\text { (in vitro) }\end{array}$ & $\begin{array}{l}\text { Sasanquasaponin derived } \\
\text { from Camellia oleifera }\end{array}$ \\
\hline [48] & $\begin{array}{l}\text { Reducing in oxidized glutathione and lipid } \\
\text { peroxidation }\end{array}$ & Extract & $\begin{array}{l}\text { Experimental } \\
\text { (in vivo) }\end{array}$ & $\begin{array}{l}\text { Oleuropein derived } \\
\text { from Olea europaea oil }\end{array}$ \\
\hline [49] & \begin{tabular}{|l|} 
Protecting rat aorta endothelial cells against \\
hypoxia and stimulating nitric oxide (NO) \\
release from endothelial cells, cytoprotection, \\
KATP channel opening and venous thrombosis \\
inhibiting
\end{tabular} & Solution & $\begin{array}{l}\text { Experimental } \\
\text { (in vitro) }\end{array}$ & $\begin{array}{l}\text { Cyclovirobuxine D derived } \\
\text { from Buxus microphylla }\end{array}$ \\
\hline$[50]$ & $\begin{array}{l}\text { Up-regulating of GSH and inhabitation } \\
\text { of deplete cellular GSH level. The } \\
\text { 12-O-tetradecanoylphorbo-13-acetate response } \\
\text { element or the antioxidant response element } \\
\text { may be involved in the transactivating actions } \\
\text { of andrographolide on the catalytic subunit } \\
\text { (GCLC) and modifier subunit (GCLM) } \\
\text { promoters }\end{array}$ & Solution & $\begin{array}{l}\text { Experimental } \\
\text { (in vitro) }\end{array}$ & $\begin{array}{l}\text { Andrographolide derived } \\
\text { from Andrographis Paniculata }\end{array}$ \\
\hline [51] & $\begin{array}{l}\text { Down-regulating gene expression levels of pro- } \\
\text { apoptotic genes such as Bax and Fas proteins. } \\
\text { But it up-regulating Bcl-2 and Bcl-xl proteins. } \\
\text { In addition inducing the anti-oxidant enzymes } \\
\text { SOD and CAT }\end{array}$ & Extract & $\begin{array}{l}\text { Experimental } \\
\text { (in vitro) }\end{array}$ & Leonurine derived from Herba leonuri \\
\hline [52] & $\begin{array}{l}\text { Insert anti-apoptotic effects by activating the } \\
\text { PI3K/AKT/GSK3 } \beta \text { pathway and reduced } \\
\text { apoptosis }\end{array}$ & Solution & $\begin{array}{l}\text { Experimental } \\
\text { (in vitro and } \\
\text { in vivo) }\end{array}$ & Leonurine \\
\hline [53] & $\begin{array}{l}\text { Increasing the Akt phosphorylation, reducing } \\
\text { gene expression of Bcl-2, but it reducing the } \\
\text { gene expression of Bax in vivo. In addition } \\
\text { increasing the expression of HIF-1 } \alpha \text { but also } \\
\text { the expression of survivin and VEGF }\end{array}$ & Extract & $\begin{array}{l}\text { Experimental } \\
\text { (in vitro and } \\
\text { in vivo) }\end{array}$ & Leonurine \\
\hline [54] & $\begin{array}{l}\text { Down-regulating gene expression levels of } \\
\text { proapoptotic genes (Bax, Fas and caspase-3) } \\
\text { and up-regulating Bcl-2. Besides it can } \\
\text { increasing in SOD content }\end{array}$ & $\begin{array}{l}\text { Methanolic } \\
\text { extract }\end{array}$ & $\begin{array}{l}\text { Experimental } \\
\text { (in vitro) }\end{array}$ & $\begin{array}{l}\text { Hirsutine derived from Uncaria } \\
\text { rhynchophylla }\end{array}$ \\
\hline [55] & $\begin{array}{l}\text { Modulating the PI3K/Akt pathway and } \\
\text { reducing hypoxia-induced apoptosis }\end{array}$ & Solution & $\begin{array}{l}\text { Experimental } \\
\text { (in vitro) }\end{array}$ & $\begin{array}{l}\text { 3,5-dimethoxy-4-(3-(2-carbonyl- } \\
\text { ethyldisulfanyl)-propionyl) } \\
\text { derived from Herba Leonuri }\end{array}$ \\
\hline [56] & $\begin{array}{l}\text { Reducing cardiac Troponin I (cTnI) secretion } \\
\text { in serum and attenuated the Ca2+ overload } \\
\text { in cardiomyocytes and modulated the ATP- } \\
\text { sensitive potassium channel (KATP) signaling } \\
\text { pathway }\end{array}$ & Solution & $\begin{array}{l}\text { Experimental } \\
\text { (in vitro and } \\
\text { in vivo) }\end{array}$ & Saponins derived from Panax ginseng \\
\hline [57] & $\begin{array}{l}\text { Attenuating A/R-induced inflammatory } \\
\text { response and apoptosis that related to the } \\
\text { TLR4/NF-kB signaling pathway }\end{array}$ & Solution & $\begin{array}{l}\text { Experimental } \\
\text { (in vitro) }\end{array}$ & $\begin{array}{l}\text { Resveratrol derived from } \\
\text { wide variety of plant species }\end{array}$ \\
\hline
\end{tabular}


Continuation of table 2

\begin{tabular}{|c|c|c|c|c|}
\hline$[58]$ & $\begin{array}{l}\text { Up-regulating miR-133 expression via } \\
\text { activating MAPK ERK1/2 pathway and } \\
\text { enhanced cell resistant to hypoxic condition }\end{array}$ & Extract & $\begin{array}{l}\text { Experimental } \\
\text { (in vitro) }\end{array}$ & $\begin{array}{l}\text { Tanshinone IIA derived } \\
\text { from Salvia miltiorrhiza }\end{array}$ \\
\hline [59] & $\begin{array}{l}\text { Reducing myocardial infarct size, serum } \\
\text { levels of TNF-alpha, and platelet aggregation. } \\
\text { Besides reducing apoptosis via down-regulated } \\
\text { the expression of cleaved caspase-3, and up- } \\
\text { regulating the expression of phosphorylated } \\
\text { Akt }\end{array}$ & Solution & $\begin{array}{l}\text { Experimental } \\
\text { (in vitro and } \\
\text { in vivo) }\end{array}$ & $\begin{array}{l}\text { Citric acid and L-malic acid } \\
\text { derived from Fructus choerospondiatis }\end{array}$ \\
\hline$[60]$ & $\begin{array}{l}\text { Attenuating inflammation of cardiomyocytes } \\
\text { via inhibiting ERK1/2 and JNK signaling } \\
\text { pathways }\end{array}$ & Solution & $\begin{array}{l}\text { Experimental } \\
\text { (in vitro) }\end{array}$ & $\begin{array}{l}\text { Sparstolonin B derived } \\
\text { from Sparganium stoloniferum }\end{array}$ \\
\hline$[61]$ & $\begin{array}{l}\text { Inhibiting the adhesion between human cardiac } \\
\text { microvascular endothelial cells (HCMECs) } \\
\text { and polymorphonuclear leukocyte( PMN), } \\
\text { through down regulation of the expression and } \\
\text { phosphorylationofp } 38 \text { MAPK }\end{array}$ & Extract & $\begin{array}{l}\text { Experimental } \\
\text { (in vitro) }\end{array}$ & $\begin{array}{l}\text { Astragalus polysaccharide derived from } \\
\text { Astragulus }\end{array}$ \\
\hline$[62]$ & $\begin{array}{l}\text { Attenuating myocardial iscemic via activating } \\
\text { hypoxia inducible factor-1a }(\mathrm{HIF}-1 \alpha) \text { /inducible } \\
\text { nitric oxide synthase (iNOS) pathway. Besides } \\
\text { up-regulating of the Bcl2 protein and down- } \\
\text { regulating of the caspase3 protein }\end{array}$ & Solution & $\begin{array}{l}\text { Experimental } \\
\text { (in vitro) }\end{array}$ & $\begin{array}{l}\text { Astragaloside IV derived } \\
\text { from Astragalus membranaceus }\end{array}$ \\
\hline$[63]$ & $\begin{array}{l}\text { Stimulated the mitochondrial ATP generation } \\
\text { and mitochondrial respiration. Up-regulating of } \\
\text { cellular glutathione redox cycling and reducing } \\
\text { apoptosis }\end{array}$ & Solution & Ex-vivo & $\begin{array}{l}\beta \text {-sitosterol derived } \\
\text { from Cistanche deserticola }\end{array}$ \\
\hline$[64]$ & $\begin{array}{l}\text { Protecting hypoxia induced inflammation } \\
\text { by attenuating cyclooxygenase-2 (COX-2) } \\
\text { mediated cell apoptosis, and the death of } \\
\text { endothelial cells through oxidative stress } \\
\text { reduction }\end{array}$ & Decoction & $\begin{array}{l}\text { Experimental } \\
\text { (in vitro and } \\
\text { in vivo) }\end{array}$ & $\begin{array}{l}\text { Baicalein sulfates/glucuronides and } \\
\text { wogonin ssulfates/glucuronides } \\
\text { derived from Scutellaria } \\
\text { baicalensis Georgi }\end{array}$ \\
\hline$[65]$ & $\begin{array}{l}\text { Decreasing LDH release and increasing in Bcl- } \\
2 \text { and a decrease in active caspase-3 expression } \\
\text { and suppress apoptosis by activating the PI3K/ } \\
\text { Akt/eNOS signaling pathway }\end{array}$ & Solution & $\begin{array}{l}\text { Experimental } \\
\text { (in vitro and } \\
\text { in vivo) }\end{array}$ & $\begin{array}{l}\text { Breviscapine derived } \\
\text { from Erigeron breviscapus }\end{array}$ \\
\hline$[66]$ & $\begin{array}{l}\text { Decreasing serum levels of CK-MB, TNF- } \alpha \text {, } \\
\text { IL-6, LDH, SOD, and MDA. Besides, can } \\
\text { cause increasing SOD activity and decreased } \\
\text { MDA content in myocardial tissue. In addition } \\
\text { preventing myocardial injury via regulation of } \\
\text { Nox/NF-kB/AP1 pathway }\end{array}$ & Solution & $\begin{array}{l}\text { Experimental } \\
\text { (in vitro and } \\
\text { in vivo) }\end{array}$ & $\begin{array}{l}\text { Salidroside derived } \\
\text { from Rhodiola rosea }\end{array}$ \\
\hline$[67]$ & $\begin{array}{l}\text { Reversing Bax/Bcl-2 ratio and inhibiting } \\
\text { the activities of caspase-3 and caspase-9, } \\
\text { increasing mitochondrial function, by } \\
\text { reducing ROS accumulation, improving } \\
\text { mitochondrial membrane potential and } \\
\text { decreasing intracellular calcium concentration } \\
\text { and supressing apoptotic myocyte death by } \\
\text { reducing Akt/GSK-3 } \beta \text { pathway activating }\end{array}$ & Solution & $\begin{array}{l}\text { Experimental } \\
\text { (in vitro) }\end{array}$ & $\begin{array}{l}\text { Asiatic acid derived } \\
\text { from Centella asiatica }\end{array}$ \\
\hline$[68]$ & $\begin{array}{l}\text { Inhibiting apoptosis by reversing mitochondrial } \\
\text { dysfunction, due to activation of GLP-1R and } \\
\text { PI3K/AKT signaling pathway and reducing } \\
\text { oxidative stress. }\end{array}$ & Solution & $\begin{array}{l}\text { Experimental } \\
\text { (in vitro) }\end{array}$ & $\begin{array}{l}\text { Geniposide derived from } \\
\text { Gardenia jasminoides J. Ellis }\end{array}$ \\
\hline
\end{tabular}


Continuation of table 2

\begin{tabular}{|c|c|c|c|c|}
\hline$[69]$ & $\begin{array}{l}\text { Activating AMPK-mTORC1 signaling } \\
\text { pathway to initiate autophagy and improving } \\
\text { the Beclin } 1 / \text { Bcl- } 2 \text { interaction by regulating } \\
\text { their phosphorylation to prevent further } \\
\text { autophagy }\end{array}$ & Solution & $\begin{array}{l}\text { Experimental } \\
\text { (in vitro) }\end{array}$ & $\begin{array}{l}\text { Orientin derived } \\
\text { from Polygonum orientale } L .\end{array}$ \\
\hline [70] & $\begin{array}{l}\text { Decreasing fibrosis, oxidative stress, } \\
\text { inflammatory response, and hypoxia induce } \\
\text { cardiomyocyte apoptosis and activating the } \\
\text { eNOS/NO signaling cascades }\end{array}$ & Solution & $\begin{array}{l}\text { Experimental } \\
\text { (in vitro and } \\
\text { in vivo) }\end{array}$ & Orientin \\
\hline [71] & Alkaloeid compound increasing cell viability & Extract & $\begin{array}{l}\text { Experimental } \\
\text { (in vitro) }\end{array}$ & $\begin{array}{l}\text { hexahydrobenzo[c] phenanthridine } \\
\text { alkaloids derived from Corydais } \\
\text { ambigua var. amurensis }\end{array}$ \\
\hline [72] & $\begin{array}{l}\text { Protective effects toward H9c2 cells injury by } \\
\text { increasing cell viability }\end{array}$ & Extract & $\begin{array}{l}\text { Experimental } \\
\text { (in vitro) }\end{array}$ & $\begin{array}{l}\text { C21 steroidal glycosides derived } \\
\text { from Cynanchum stauntonii }\end{array}$ \\
\hline [73] & $\begin{array}{l}\text { Decreasing apoptosis and inhibited the } \\
\text { activities of renin and angiotensin-converting } \\
\text { enzyme and reducing the expression of } \\
\text { angiotensin }\end{array}$ & Extract & $\begin{array}{l}\text { Experimental } \\
\text { (in vitro and } \\
\text { in vivo) }\end{array}$ & $\begin{array}{l}\text { Trans-polydatin derived from } \\
\text { polygonum cuspidatum }\end{array}$ \\
\hline [74] & $\begin{array}{l}\text { Diminishing the protein level of cleaved } \\
\text { caspase-3, LC3-II, Beclin1 and Sirt1 and } \\
\text { suppressing autophagy and apopotosis }\end{array}$ & Extract & $\begin{array}{l}\text { Experimental } \\
\text { (in vitro) }\end{array}$ & Coptisine derived from Rhizoma coptidis \\
\hline [75] & $\begin{array}{l}\text { Up-regulation of autophagy and enhancement } \\
\text { of mitochondrial biogenesis via Sirt } 3 \text { activity }\end{array}$ & Solution & $\begin{array}{l}\text { Experimental } \\
\text { (in vitro and } \\
\text { in vivo) }\end{array}$ & $\begin{array}{l}\text { Polyphenolic derived } \\
\text { from Polygonum cuspidatum }\end{array}$ \\
\hline [76] & $\begin{array}{l}\text { Increasing pyruvate dehydrogenase-mediated } \\
\text { aerobic metabolism and restoration of aerobic } \\
\text { glucose oxidation }\end{array}$ & Solution & $\begin{array}{l}\text { Experimental } \\
\text { (in vitro) }\end{array}$ & $\begin{array}{l}\text { Panax notoginseng saponin derived } \\
\text { from Panax notoginseng }\end{array}$ \\
\hline [77] & $\begin{array}{l}\text { Enhancement of autophagic flux and removal } \\
\text { of dysfunction of mitochondria }\end{array}$ & Solution & $\begin{array}{l}\text { Experimental } \\
\text { (in vitro and } \\
\text { in vivo) }\end{array}$ & Gastrodin derived from Gastrodia elata \\
\hline [78] & $\begin{array}{l}\text { Reducing oxidative stress and apoptosis via } \\
\text { affecting ER } \alpha \text { and GPR } 30 \text { to activation PI3K } \\
\text { pathway and its downstream apoptosis proteins }\end{array}$ & Solution & $\begin{array}{l}\text { Experimental } \\
\text { (in vitro) }\end{array}$ & $\begin{array}{l}\text { Notoginsenoside } \mathrm{R} 1 \text { derived } \\
\text { from Panax notoginsenosides }\end{array}$ \\
\hline [79] & $\begin{array}{l}\text { Regulation of mitochondrial pathway } \\
\text { (mediated by } 14-3-3 \eta \text { signaling pathway) }\end{array}$ & Solution & $\begin{array}{l}\text { Experimental } \\
\text { (in vitro) }\end{array}$ & $\begin{array}{l}\text { Luteoloside } \\
\text { derived from several Chinese medicines }\end{array}$ \\
\hline [80] & $\begin{array}{l}\text { Down-regulating miR-22 expression and } \\
\text { activating the PI3K/AKT and JAK1/STAT3 } \\
\text { pathways and reduced apoptosis }\end{array}$ & Solution & $\begin{array}{l}\text { Experimental } \\
\text { (in vitro) }\end{array}$ & Angelica sinensis polysaccharide \\
\hline [81] & $\begin{array}{l}\text { Recovering the Activated Peroxisome } \\
\text { Proliferator- Receptor- } \gamma(\text { PPAR- } \gamma) \text { and eNOS } \\
\text { pathway activity and reduced apoptosis and } \\
\text { inflammatory response }\end{array}$ & Solution & $\begin{array}{l}\text { Experimental } \\
\text { (in vitro) }\end{array}$ & $\begin{array}{l}\text { Emodin derived } \\
\text { from Rheum palmatum } L .\end{array}$ \\
\hline [82] & $\begin{array}{l}\text { Attenuating oxidative abnormalities and } \\
\text { modulating the antiapoptotic proteins. }\end{array}$ & $\begin{array}{l}\text { Methanolic } \\
\text { extract }\end{array}$ & $\begin{array}{l}\text { Experimental } \\
\text { (in vitro) }\end{array}$ & Rutin derived from Spermococe hispida \\
\hline [83] & $\begin{array}{l}\text { Restoration autophagic flux via activation of } \\
\text { PI3K/Akt/mTOR signaling pathway }\end{array}$ & $\begin{array}{l}\text { Ethanolic } \\
\text { extract }\end{array}$ & $\begin{array}{l}\text { Experimental } \\
\text { (in vitro and } \\
\text { in vivo) }\end{array}$ & $\begin{array}{l}\text { Lactone derived } \\
\text { from Ligusticum chuanxiong }\end{array}$ \\
\hline [84] & $\begin{array}{l}\text { Rising cellular antioxidant defense capacity } \\
\text { via inducing the phosphorylation of AKT } \\
\text { and subsequently activating the Nrf2/HO-1 } \\
\text { signaling pathway }\end{array}$ & Solution & $\begin{array}{l}\text { Experimental } \\
\text { (in vitro and } \\
\text { in vivo) }\end{array}$ & $\begin{array}{l}\text { Total flavonoids derived } \\
\text { from Clinopodium chinense }\end{array}$ \\
\hline
\end{tabular}


Continuation of table 2

\begin{tabular}{|l|l|l|l|l|}
\hline$[85]$ & $\begin{array}{l}\text { Inhibiting self-cleavage of OMA1, causing } \\
\text { to attenuate OPA1 cleavage and reducing } \\
\text { apoptosis }\end{array}$ & Solution & $\begin{array}{l}\text { Experimental } \\
\text { (in vitro })\end{array}$ & $\begin{array}{l}\text { Epigallocatechin gallate derived } \\
\text { from Camellia sinensis }\end{array}$ \\
\hline$[86]$ & $\begin{array}{l}\text { Inhibiting PI3K/AKT-mediated ER stress, } \\
\text { apoptosis and oxidative stress }\end{array}$ & Solution & $\begin{array}{l}\text { Experimental } \\
\text { (in vitro } \\
\text { and ex vivo })\end{array}$ & $\begin{array}{l}\text { Tournefolic acid B derived } \\
\text { from Clinopodium chinense }\end{array}$ \\
\hline
\end{tabular}

Medicinal plants and their derivatives analyzed in Table 2 provide their cardioprotective effects through several mechanisms, such as follows.

Antioxidant activity. Oxidative stress and ROS have been proven to be a potent inducer of oxidative injury, programmed cell death i.e. apoptosis [87]. ROS, which have highly toxic and reactive properties, generated due to ischaemia and augment the degree of myocardial damage sustained by the ischaemic myocardium. To cope with these toxic agents humans developed a natural defense system. The defense mechanisms include enzymes, such as SOD, GPX, CAT, guaiacol peroxidase (POX), peroxiredoxins (Prxs), ascorbate-glutathione (AsA-GSH), ascorbate peroxidase (APX), monodehydroascorbate reductase (MDAR), dehydroascorbate reductase (DHAR) and glutathione reductase (GR) [88]. Another cardioprotective mechanism is preventing myocardial injury via regulation or or activation of pathways that contribute to antioxidant activity. For instance, herbal compounds regulatied Nox/NF- $\mathrm{kB} / \mathrm{AP} 1$ pathway, which causes nonmitochondrial cellular ROS and inflammatory cytokines generation through the multiple signal pathways [66]. Another antioxidant pathway is activation of eNOS. Phytochemicals can increase NO production in heart and inhibit superoxide by quenching it [70]. Also activation of PI3 K/ Akt signaling pathway can suppress mitochondrialdependent apoptosis and oxidative stress, by activating HO-1 and NQO1, which are Nrf2 mediated-antioxidants [21; 84]. Under pathological conditions, for instance, myocardium infraction and stroke, this defense system is disrupted. Consequently, generation of free radicals increases and the scavenging effects of antioxidants, leading to oxidative damage to cardiomyocytes. Medicinal herbs contain polyphenols that attenuate the level of oxidizing agents and can directly scavenge hydrogen peroxide, superoxide and hydroxyl radicals, increasing the cardiomyocytes viability and reducing the infarct size [14].

Anti-apoptotic properties. ROS induces cell dysfunction and cardiomyocytes necrosis via other mechanisms. They stimulate and activate calpains and metalloproteinases, mitochondrial permeability transition pore (MPTP) opening which cause to swelling and lysis of cardiomyocytes. This process may cause release of pro-apoptotic factors in the cytosol, so this mechanism is contributing to cell death [89]. Hence, another cardioprotective mechanism of medicinal plants and their derivatives is regulating pro-apoptotic genes in cardiomyocytes hypoxic condition. They can down-regulating gene expression levels of pro-apoptotic genes such as Bax, Fas, caspase- 3 and caspase- 9 proteins. In addition they can up-regulating Bcl-2 and Bcl-xl proteins [51; 54; 57]. Another protective mechanism is prevented a reduction in cell viability, decreased the amount of lactate dehydrogenase (LDH) activity release, which is used as indicators of cardiomyocyte injury and improved cell viability [57]. Also they can protect cardiomyocytes against hypoxia via suppress multiple signaling pathways such as PKC epsilon/mK ATP and redox-sensitive ERK/Nrf2 and TLR4/NF- $\kappa B$ pathways, which attributed ROS arising from CYPcatalyzed processes and apoptosis trigger [23; 57]. They also can suppress apoptosis through activating the AMPK, PI3K/Akt/eNOS, GLP-1R, PI3K/AKT, JAK1/STAT3 and Akt/GSK-3 $\beta$ signaling pathways that plays important roles in cell survival and apoptosis $[13 ; 33 ; 67 ; 68 ; 80]$ and regulating Akt/Nrf2/ HO-1 signaling. Up-regulation of eNOS can protect against myocardial infarction injury via suppressing vascular cell adhesion molecule expression and preventing excessive leukocyte tissue infiltration. In addition phytochemicals increasing hemeoxygenase-1 (HO-1), which is an inducible enzyme with potent antioxidant activity [32]. Thus, phytochemicals upregulating MAPK ERK1/2 pathway and modulating the PI3K/Akt pathway and reduced apoptosis in cardiomyocytes $[55 ; 58]$. Besides, phytochemical prevented cytochrome $\mathrm{c}$ release to protect cardiomyocytes from apoptosis via activation some pathways [85].

Reducing the calcium influx. During the acute myocardial ischemia, results in reduction of ATP production and cell metabolism switch to anaerobic 
glycolysis due to lack of oxygen. It can cause a drop in intracellular $\mathrm{pH}$ and the production of lactate. This induces ion pump function unbalance and the $\mathrm{Na}^{+}-$ $\mathrm{H}^{+}$exchanger to extrude $\mathrm{H}+$ and causes in intracellular $\mathrm{Na}+$ accumulation, which activates the $2 \mathrm{Na}^{+}-\mathrm{Ca}^{2+}$ exchanger to function in inverse to throw out $\mathrm{Na}+$ and results intracellular $\mathrm{Ca}^{2+}$ overload [4]. Polyphenols, such as flavonoids components, inhibited $\left[\mathrm{Ca}\left({ }^{2+}\right)\right]$ $\mathrm{i}$ contents in cardiac muscle cells and prevented the changes induced by $\mathrm{KCl}$ in cardiac myocytes and $\mathrm{K}$ ATP channel-opening in the cardiac myocytes has been may attributed to reduced $\mathrm{Ca}^{2+}$ influx. They can consequently prolong hypoxia endurance time in cardiac myocytes $[17 ; 56]$. Besides in molecule assay, they reduced sensitivity to $\mathrm{Ca}^{2+}$-induced mitochondrial permeability transition (MPT) pore opening and reduced necrotic and apoptotic cell death in hypoxic/ reoxygenated cardiac myocytes [23]. Also medicinal plants suppress increased in the late sodium current $(\mathrm{INaL})$ that induce intracellular $\mathrm{Na}(+)$ overload and finally intracellular $\left.\mathrm{Ca}^{(2+}\right)$ overload through activated reverse $\mathrm{Na}\left({ }^{+}\right)-\mathrm{Ca}\left({ }^{2+}\right)$ exchange [35].

Antiinflammatory properties. After cardiac reperfusion, inflammatory cascade is triggered and a lot of amounts of pro-inflammatory cytokines like TNF-alpha, IL-1beta, IL-6, and IL-8 are produced and released. These cytokines as main factors in cardiac dysfunction activate neutrophils and endothelial cells and exacerbate myocardial ischemic injury [90]. Therefore inflammation is a detrimental factor in myocyte hypoxia. It has been proven that TLR2 and TLR4 are expressed in cardiomyocytes during myocardial infarction injury and their stimulation by local endogenous ligands results to the up-regulation of their own expression. These two toll-like receptors are mediate to inflammatory receptors. Some medicinal derivatives can attenuate hypoxia-reoxygenation-induced inflammation, via extracellular signal-regulated kinase 1 or 2 (ERK1/2) and c-Jun NH2-terminal kinase (JNK) signaling pathways [60]. ROS generation during hypoxia causes inflammatory responses that activate including the expression of COX-2 and intercellular adhesion molecule 1 (ICAM-1), which plays a pivotal role in the linkage between inflammation and apoptosis [91]. Inhibitory effect of medicinal plants on expression of inflammatory neutrophils or gene response and consequently this property can increase cell viability and reduce necrosis volume [57; 64]. One of these related mechanisms is decreasing peroxidase enzyme like MPO, which has both oxidative and inflammatory effects in cardiomyocytes [38]. MPO is an inflammatory marker, elevated in ischemic cases [92]; so inhibiting that

Int. j. biol. chem. (Online) is one of the anti inflammatory effects of medicinal herbs. HIF- $1 \alpha$ is known as principal regulator of the molecular hypoxic response and has regulator effect on the cellular and systemic homeostatic responses to hypoxic circumstances by activating the transcription of several genes, consisting those involved in energy metabolism, apoptosis, angiogenesis, other genes, the protein products of which augment oxygen delivery or assist metabolic adaptation to hypoxia [93]. HIF-1 $\alpha$ has a vital role in triggering cellular protection and metabolic alterations in response to oxygen deprivation during myocardial ischemia and adaptive response to cell ischemia and hypoxia [94].

Some herbal compounds can attenuate myocardial ischemia reperfusion injury by up-regulating HIF-1 $\alpha$ expression which transmits a survival signal to the myocardium [62]. For example, promoting HIF- $1 \alpha$ expression causes the inhibition of ROS generation, maintenance of mitochondrial membrane potential (MMP) and reduction of calcium influx, so inhibiting the mitochondrial-mediated apoptosis in hypoxic cardiomyocytes [67]. Even so, some studies reported that HIF-1 is negatively attributed to bcl-2 expression and enhancement apoptosis [33; 95]. Several plants can implement their cardioprotective effects by decreasing HIF- $1 \alpha$ expression after several weeks [33].

The role of autophagy in myocardial hypoxic injury is still controversial. It is believed that cardiomyocyte necrosis may occur via autophagy upregulation and through excessive degradation of the necessary cellular components and self-digestion after hypoxia/reoxygenation or ischemic injury [96]. Medicinal plants active compounds can act as the inhibitor of autolysosome, suggesting that they may inhibit autophagosome generation that consequently enhanced cell viability and decreased apoptosis [36; 74]. However some studies indicate that medicinal plants and their derivatives insert their protective effects through up-regulating autophagy along with enhanced autophagic flux via the activation of various pathways $[27 ; 77 ; 83]$. Clearly, autophagy is dysregulated in the process of myocardial hypoxia injury and herbal compounds can restore unbalance in autophagy process and regulating phosphorylation to prevent excessive autophagy.

\section{Conclusion}

It should be noted that plant and their derivatives are not always beneficial and their misuse can lead to irreparable complications. For instance, application of methylcysteine, derived from Allium sativum 
in mice caused toxic effects to the heart. High dose consumption of this compound causes up-regulation of apoptotic genes (Bax and caspase3), hypoxia inducible factor 1 alpha (HIF1a) and down-regulation of the anti-apoptotic marker, Bcl2. It causes hypoxia induced cardiomyocyte apoptosis attributed by engulfment of mitochondria by nucleus [97]. Most of the reviewed studies were carried out on animal hypoxic or ischemic models and on $\mathrm{H} 9 \mathrm{c} 2$ cells; so they cannot be generalized in human and it was one of the main limitations of the studies. Medicinal herbs can be used as an effective treatment against myocardial hypoxia mainly through antioxidant, anti apoptosis, anti-inflammatory properties, inhibiting calcium accumulation, HIF-1 $\alpha$ signaling regulation and autophagy regulation. Post-ischemia and chronic treatment of cardioprotection maybe consider as a therapeutic strategies than short term and pre-treatment methods in clinical setting. More clinical trial studies are required in order to obtain more reliable results.

\section{References}

1. Mozaffarian D., Benjamin E.J., Go A.S., Arnett D.K., Blaha M.J., Cushman M., et al. (2015). Heart disease and stroke statistics-2015 update: a report from the American Heart Association. Circulation, vol. 131, no. 4, pp. e29-322.

2. Cahill T.J., Kharbanda R.K. (2017). Heart failure after myocardial infarction in the era of primary percutaneous coronary intervention: mechanisms, incidence and identification of patients at risk. World J Cardiol., vol. 9, no. 5, pp. 407-415.

3. Neri M., Riezzo I., Pascale N., Pomara C., Turillazzi E. (2017). Ischemia/Reperfusion injury following acute myocardial infarction: a critical issue for clinicians and forensic pathologists. Media Inflam., vol. 2017, no., pp. 7018393-7018393.

4. Hausenloy D.J., Yellon D.M. (2013). Myocardial ischemia-reperfusion injury: a neglected therapeutic target. J Clin Invest., vol. 123, no. 1, pp. 92-100.

5. Heidari-Soreshjani S., Asadi-Samani M., Yang Q., Saeedi-Boroujeni A. (2017). Phytotherapy of nephrotoxicity-induced by cancer drugs: an updated review. J Nephropathol., vol. 6, no. 3, pp. 254263.

6. Memarzadeh E., Luther T., Heidari-Soureshjani S. (2018). Effect and mechanisms of medicinal plants on dry eye disease: a systematic review. J Clin Diagn Res., vol. 12, no. 9, pp. NE1-NE4.
7. Shabanian G., Heidari-Soureshjani S., Rafieian-Kopaei M., Saadat M., Shabanian M. (2017). Therapeutic effects of Quercus persica fruit skin on healing of second-degree burn wounds in animal model. J Zanjan Univ Med SciHealth Servs., vol. 25, no. 113, pp. 81-92.

8. Shabanian S., Khalili S., Lorigooini Z., Malekpour A., Heidari-Soureshjani S. (2017). The effect of vaginal cream containing ginger in users of clotrimazole vaginal cream on vaginal candidiasis. $J$ Adv Pharm Technol Res., vol. 8, no. 2, pp. 80-84.

9. Shirani M., Raeisi R., Heidari-Soureshjani S., Asadi-Samani M., Luther T. (2017). A review for discovering hepatoprotective herbal drugs with least side effects on kidney. $J$ Nephropharmacol., vol. 6, no. 2, pp. 38-48.

10. Yavangi M., Rabiee S., Nazari S., FarimaniSanoee M., Amiri I., Bahmanzadeh M., et al. (2018). Comparison of the Effect of Oestrogen Plus Foeniculum vulgare Seed and Oestrogen alone on Increase in Endometrial Thickness in Infertile Women. J. Clin. Diagn. Res., vol. 12, no. 1, pp. QC01-QC04.

11. Heidari-Soreshjani S., Asadi-Samani M., Yang Q., Saeedi-Boroujeni A. (2017). Phytotherapy of nephrotoxicity-induced by cancer drugs: an updated review. J Nephropathol., vol. 6, no. 3, pp. 254263.

12. Shirani-Boroujeni M., Heidari-Soureshjani S., Keivani Hafshejani Z. (2017). Impact of oral capsule of Peganum harmala on alleviating urinary symptoms in men with benign prostatic hyperplasia; a randomized clinical trial. J Renal Inj Prev, vol. 6, no. 2, pp. 127-131.

13. Li F., Fan X., Zhang Y., Pang L., Ma X., Song M., et al. (2016). Cardioprotection by combination of three compounds from ShengMai preparations in mice with myocardial ischemia/reperfusion injury through AMPK activation-mediated mitochondrial fission. Sci Rep., vol. 6, 37114.

14. Shao Z.H., Li C.Q., Vanden Hoek T.L., Becker L.B., Schumacker P.T., Wu J.A., et al. (1999). Extract from Scutellaria baicalensis Georgi attenuates oxidant stress in cardiomyocytes. $J \mathrm{Mol}$ Cell Cardiol., vol. 31, no. 10, pp. 1885-1895.

15. Fitzl G., Welt K., Wassilew G., Clemens N., Penka K., Mukke N. (2001). The influence of hypoxia on the myocardium of experimentally diabetic rats with and without protection by Ginkgo biloba extract. III: Ultrastructural investigations on mitochondria. Exp Toxicol Pathol., vol. 52, no. 6, pp. 557-568. 
16. Gao X.F., Shi H.M., Sun T., Ao H. (2009). Effects of Radix et rhizoma Rhodiolae kirilowii on expressions of von Willebrand factor, hypoxiainducible factor 1 and vascular endothelial growth factor in myocardium of rats with acute myocardial infarction. Zhong Xi Yi Jie He Xue Bao, vol. 7, no. 5, pp. 434-440.

17. Zhang B.N., Hou Y.L., Liu B.J., Liu Q.M., Qiao G.F. (2010). The Rhododendron dauricum L. flavonoids exert vasodilation and myocardial preservation. Iran J Pharm Res., vol. 9, no. 3, pp. 303-311.

18. Wang Z., Liao S.G., He Y., Li J., Zhong R.F., He X., et al. (2013). Protective effects of fractions from Pseudostellaria heterophylla against cobalt chloride-induced hypoxic injury in $\mathrm{H} 9 \mathrm{c} 2$ cell. $J$ Ethnopharmacol, vol. 147, no. 2, pp. 540-545.

19. Wong H.S., Ko K.M. (2013). Herba Cistanches stimulates cellular glutathione redox cycling by reactive oxygen species generated from mitochondrial respiration in $\mathrm{H} 9 \mathrm{c} 2$ cardiomyocytes. Pharm Biol., vol. 51, no. 1, pp. 64-73.

20. Lim C.Y., Kim B.Y., Lim S.H., Cho S.I. (2015). Effects of Pogostemon cablin Blanco extract on hypoxia induced rabbit cardiomyocyte injury. Pharmacogn Mag., vol. 11, no. 42, pp. 311-319.

21. Li L., Zhou Y., Li Y., Wang L., Sun L., Zhou L., et al. (2017). Aqueous extract of Cortex Dictamni protects $\mathrm{H} 9 \mathrm{c} 2$ cardiomyocytes from hypoxia/reoxygenation-induced oxidative stress and apoptosis by PI3K/Akt signaling pathway. Biomed Pharmacother., vol. 89, no., pp. 233-244.

22. Yang G., Min D., Yan J., Yang M., Lin G. (2018). Protective role and mechanism of snakegourd peel against myocardial infarction in rats. Phytomed., vol. 42 , no., pp. 18-24.

23. Chiu P.Y., Leung H.Y., Leong P.K., Chen N., Zhou L.M., Zuo Z., et al. (2012). Danshen-Gegen decoction protects against hypoxia/reoxygenationinduced apoptosis by inhibiting mitochondrial permeability transition via the redox-sensitive ERK/ Nrf2 and PKC epsilon/mK ATP pathways in H9c2 cardiomyocytes. Phytomed., vol. 19, no. 2, pp. 99110.

24. Hu F., Koon C.M., Chan J.Y., Lau K.M., Fung K.P. (2012). The cardioprotective effect of danshen and gegen decoction on rat hearts and cardiomyocytes with post-ischemia reperfusion injury. BMC Complement Altern Med., vol. 12, p. 249.

25. Xu M., Hao H., Jiang L., Wei Y., Zhou F., Sun J., et al. (2016). Cardiotonic pill reduces myocardial ischemia-reperfusion injury via increasing EET concentrations in rats. Drug Metab Dispos., vol. 44, no. 7 , pp. 878-887.

26. Wei W., Liu Y., Zhang Q., Wang Y., Zhang X., Zhang H. (2017). Danshen-Enhanced cardioprotective effect of cardioplegia on ischemia reperfusion injury in a human-induced pluripotent stem cell-derived cardiomyocytes model. Artif Organs., vol. 41, no. 5, pp. 452-460.

27. Cui H., Li X., Li N., Qi K., Li Q., Jin C., et al. (2014). Induction of autophagy by Tongxinluo through the MEK/ERK pathway protects human cardiac microvascular endothelial cells from hypoxia/ reoxygenation injury. J Cardiovasc Pharmacol., vol. 64, no. 2, pp. 180-190.

28. Li Q., Cui H.H., Yang Y.J., Li X.D., Chen G.H., Tian X.Q., et al. (2017). Quantitative Proteomics Analysis of Ischemia/Reperfusion InjuryModulated Proteins in Cardiac Microvascular Endothelial Cells and the Protective Role of Tongxinluo. Cell Physiol Biochem., vol. 41, no. 4, pp. 1503-1518.

29. Qi K., Li X., Geng Y., Cui H., Jin C., Wang P., et al. (2018). Tongxinluo attenuates reperfusion injury in diabetic hearts by angiopoietin-like 4-mediated protection of endothelial barrier integrity via PPAR-alpha pathway. PLoS One, vol. 13, no. 6, pp. e0198403.

30. Wang W., Wang L., Yang H., Wang J., Yin X., Xu H., et al. (2014). Protective effects of yindanxinnaotong capsule in a rat model of myocardial ischemia/reperfusion injury. J Tradit Chin Med., vol. 34, no. 6, pp. 699-709.

31. Duan Z.Z., Li Y.H., Li Y.Y., Fan G.W., Chang Y.X., Yu B., et al. (2015). Danhong injection protects cardiomyocytes against hypoxia/reoxygenation- and $\mathrm{H} 2 \mathrm{O} 2$-induced injury by inhibiting mitochondrial permeability transition pore opening. $J$ Ethnopharmacol., vol. 175, no., pp. 617-625.

32. Hu T., Wei G., Xi M., Yan J., Wu X., Wang Y., et al. (2016). Synergistic cardioprotective effects of Danshensu and hydroxysafflor yellow A against myocardial ischemia-reperfusion injury are mediated through the Akt/Nrf2/HO-1 pathway. Int J Mol Med., vol. 38, no. 1, pp. 83-94.

33. Yu F.C., Xu Y.J., Tong J.Y., Lu Z.Z., Zhang X.H. (2015). Therapeutic effects of Qishen Yiqi Dropping Pill on myocardial injury induced by chronic hypoxia in rats. Chin J Nat Med., vol. 13, no. 10, pp. 776-780.

34. Feng Y.Q., Ju A.C., Liu C.H., Wang T., Yu B.Y., Qi J. (2016). Protective effect of the extract of Yi-Qi-Fu-Mai preparation on hypoxia-induced 
heart injury in mice. Chin J Nat Med., vol. 14, no. 6, pp. 401-406.

35. Luo A., Liu Z., Cao Z., Hao J., Wu L., Fu C., et al. (2017). Wenxin Keli diminishes $\mathrm{Ca}\left({ }^{2+}\right)$ overload induced by hypoxia/reoxygenation in cardiomyocytes through inhibiting INaL and ICaL. Pacing Clin Electrophysiol., vol. 40, no. 12, pp. 1412-1425.

36. Shi X., Zhu H., Zhang Y., Zhou M., Tang D., Zhang H. (2017). XuefuZhuyu decoction protected cardiomyocytes against hypoxia/reoxygenation injury by inhibiting autophagy. BMC Complement Altern Med., vol. 17, no. 1, p. 325.

37. Wang D., Liu Y., Zhong G., Wang Y., Zhang T., Zhao Z., et al. (2017). Compatibility of Tanshinone IIA and astragaloside IV in attenuating hypoxia-induced cardiomyocytes injury. $J$ Ethnopharmacol., vol. 204, pp. 67-76.

38. Li F., Fan X.X., Chu C., Zhang Y., Kou J.P., Yu B.Y. (2018) A strategy for optimizing the combination of active components based on Chinese medicinal formula Sheng-Mai-San for myocardial ischemia. Cell Physiol Biochem., vol. 45, no. 4, pp. 1455-1471.

39. Li F., Guo S., Wang C., Huang X., Wang H., Tan X., et al. (2018). Yiqihuoxue decoction protects against post-myocardial infarction injury via activation of cardiomyocytes PGC-1alpha expression. BMC Complement Altern Med., vol. 18, no. 1, pp. 253.

40. Sun L., Jia H., Ma L., Yu M., Yang Y., Liu Y., et al. (2018). Metabolic profiling of hypoxia/reoxygenation injury in $\mathrm{H} 9 \mathrm{c} 2$ cells reveals the accumulation of phytosphingosine and the vital role of Dan-Shen in Xin-Ke-Shu. Phytomed., vol. 49, no., pp. 83-94.

41. Wang Y., Zhao Y., Jiang W., Zhao X., Fan G., Zhang H., et al. (2018). iTRAQ-based proteomic analysis reveals recovery of impaired mitochondrial function in ischemic myocardium by Shenmai formula. J Proteome Res., vol. 17, no. 2, pp. 794-803.

42. Zhang W.Y., Yu Y., Yan L.L., Li C., Han J.Y., Qin Z.F., et al. (2018). Discovery of cardioprotective constituents of Gualou Xiebai Decoction, a classical traditional Chinese medicinal formula. Phytomed., vol. 15, no. 54, pp. 318-327.

43. Yagi A., Okamura N., Tanonaka K., Takeo S. (1994). Effects of tanshinone VI derivatives on post-hypoxic contractile dysfunction of perfused rat hearts. Planta Med., vol. 60, no. 5, pp. 405-409.

44. Chan P., Hong C.Y., Tomlinson B., Chang N.C., Chen J.P., Lee S.T., et al. (1997). Myocardial

Int. j. biol. chem. (Online) protective effect of trilinolein: an antioxidant isolated from the medicinal plant Panax pseudoginseng. Life Sci., vol. 61, no. 20, pp. 1999-2006.

45. Chan P., Niu C.S., Tomlinson B., Hong C.T., Chen J.P., Hong C.Y., et al. (1997). Effect of trilinolein on superoxide dismutase activity and left ventricular pressure in isolated rat hearts subjected to hypoxia and normoxic perfusion. Pharmacol., vol. 55 , no. 5 , pp. 252-258.

46. Lai Z.F., Shao Z., Chen Y.Z., He M., Huang Q., Nishi K. (2004). Effects of sasanquasaponin on ischemia and reperfusion injury in mouse hearts. $J$ Pharmacol Sci., vol. 94, no. 3, pp. 313-324.

47. Chen H.P., He M., Huang Q.R., Liu D., Huang M. (2007). Sasanquasaponin protects rat cardiomyocytes against oxidative stress induced by anoxia-reoxygenation injury. Eur J Pharmacol., vol. 575, no. 1-3, pp. 21-27.

48. Manna C., Migliardi V., Golino P., Scognamiglio A., Galletti P., Chiariello M., et al. (2004). Oleuropein prevents oxidative myocardial injury induced by ischemia and reperfusion. J Nutr Biochem., vol. 15 , no. 8 , pp. 461-466.

49. Hu D., Liu X., Wang Y., Chen S. (2007). Cyclovirobuxine D ameliorates acute myocardial ischemia by K(ATP) channel opening, nitric oxide release and anti-thrombosis. Eur J Pharmacol., vol. 569, no. 1-2, pp. 103-109.

50. Woo A.Y., Waye M.M., Tsui S.K., Yeung S.T., Cheng C.H. (2008). Andrographolide up-regulates cellular-reduced glutathione level and protects cardiomyocytes against hypoxia/reoxygenation injury. J Pharmacol Exp Ther., vol. 325, no. 1, pp. 226235.

51. Liu X.H., Xin H., Hou A.J., Zhu Y.Z. (2009). Protective effects of leonurine in neonatal rat hypoxic cardiomyocytes and rat infarcted heart. Clin Exp Pharmacol Physiol., vol. 36, no. 7, pp. 696-703.

52. Xu L., Jiang X.J., Wei F., Zhu H.L. (2018). Leonurine protects cardiac function following acute myocardial infarction through anti-apoptosis by the PI3K/AKT/GSK3 beta signaling pathway. Mol Med Rep., vol. 18, no. 2, pp. 1582-1590.

53. Liu X., Pan L., Gong Q., Zhu Y. (2010). Leonurine (SCM-198) improves cardiac recovery in rat during chronic infarction. Eur J Pharmacol., vol. 649 , no. 1-3, pp. 236-241.

54. Wu L.X., Gu X.F., Zhu Y.C., Zhu Y.Z. (2011). Protective effects of novel single compound, Hirsutine on hypoxic neonatal rat cardiomyocytes. Eur J Pharmol., vol. 650, no. 1, pp. 290-297. 
55. Liu C., Guo W., Maerz S., Gu X., Zhu Y. (2013). 3,5-dimethoxy-4-(3-(2-carbonyl-ethyldisulfanyl) - propionyl)-benzoic acid 4-guanidino-butyl ester: a novel twin drug that prevents primary cardiac myocytes from hypoxia-induced apoptosis. Eur J Pharmacol., vol. 700, no. 1-3, pp. 118-126.

56. Li H.X., Han S.Y., Ma X., Zhang K., Wang L., Ma Z.Z., et al. (2012). The saponin of red ginseng protects the cardiac myocytes against ischemic injury in vitro and in vivo. Phytomed., vol. 19, no. 6, pp. 477-483.

57. Zhang C., Lin G., Wan W., Li X., Zeng B., Yang B., et al. (2012). Resveratrol, a polyphenol phytoalexin, protects cardiomyocytes against anoxia/ reoxygenation injury via the TLR4/NF-kappaB signaling pathway. Int $J$ Mol Med., vol. 29, no. 4, pp. 557-563.

58. Zhang L., Wu Y.L., Li Y.M., Xu C.Q., Li X.L., Zhu D.L., et al. (2012). Tanshinone IIA improves miR-133 expression through MAPK ERK1/2 pathway in hypoxic cardiac myocytes. Cell Physiol Biochem., vol. 30, no. 4, pp. 843-852.

59. Tang X., Liu J., Dong W., Li P., Li L., Lin C., et al. (2013). The cardioprotective effects of citric acid and L-malic acid on myocardial ischemia/ reperfusion injury. Evid Based Complement Alternat Med., vol. 2013, no., pp. 820695.

60. Liu Q., Wang J., Liang Q., Wang D., Luo Y., Li J., et al. (2014). Sparstolonin B attenuates hypoxia-reoxygenation-induced cardiomyocyte inflammation. Exp Biol Med., vol. 239, no. 3, pp. 376-384.

61. Zhu H.Y., Gao Y.H., Wang Z.Y., Xu B., Wu A.M., Xing Y.W., et al. (2013). Astragalus polysaccharide suppresses the expression of adhesion molecules through the regulation of the p38 MAPK signaling pathway in human cardiac microvascular endothelial cells after ischemia-reperfusion injury. Evid Based Complement Alternat Med., vol. 2013, 280493.

62. Si J., Wang N., Wang H., Xie J., Yang J., Yi H., et al. (2014). HIF-1alpha signaling activation by post-ischemia treatment with astragaloside IV attenuates myocardial ischemia-reperfusion injury. PLoS One, vol. 9, no. 9, pp. e107832.

63. Wong H.S., Chen N., Leong P.K., Ko K.M. (2014). beta-sitosterol enhances cellular glutathione redox cycling by reactive oxygen species generated from mitochondrial respiration: protection against oxidant injury in $\mathrm{H} 9 \mathrm{c} 2$ cells and rat hearts. Phytother Res., vol. 28, no. 7, pp. 999-1006.

64. Chao C.L., Lin S.P., Hou Y.C., Chao

Int. j. biol. chem. (Online)
P.D.L., Chang N.C., Huang Y.C., et al. (2015). Metabolites of Scutellariae radix inhibit injury of endothelial cells in hypoxia device. $J$ Med Biol Eng., vol. 35, no. 4, pp. 492-499.

65. Wang J., Ji S.Y., Liu S.Z., Jing R., Lou W.J. (2015). Cardioprotective effect of breviscapine: inhibition of apoptosis in $\mathrm{H} 9 \mathrm{c} 2$ cardiomyocytes via the $\mathrm{PI} 3 \mathrm{~K} / \mathrm{Akt} / \mathrm{eNOS}$ pathway following simulated ischemia/reperfusion injury. Pharmazie, vol. 70, no. 9, pp. 593-597.

66. Zhu L., Wei T., Chang X., He H., Gao J., Wen Z., et al. (2015). Effects of salidroside on myocardial injury in vivo in vitro via regulation of Nox/ NF-kappaB/AP1 pathway. Inflammation, vol. 38, no. 4, pp. 1589-1598.

67. Huang X., Zuo L., Lv Y., Chen C., Yang Y., $\mathrm{Xin}$ H., et al. (2016). Asiatic acid attenuates myocardial ischemia/reperfusion injury via Akt/GSK-3beta/ HIF-1alpha signaling in rat $\mathrm{H} 9 \mathrm{c} 2$ cardiomyocytes. Molecules, vol. 21, no. 9, pp.1248.

68. Jiang Y.Q., Chang G.L., Wang Y., Zhang D.Y., Cao L., Liu J. (2016). Geniposide prevents hypoxia/reoxygenation-induced apoptosis in H9c2 cells: improvement of mitochondrial dysfunction and activation of GLP-1R and the PI3K/AKT signaling pathway. Cell Physiol Biochem., vol. 39, no. 1, pp. 407-421.

69. Liu L., Wu Y., Huang X. (2016). Orientin protects myocardial cells against hypoxia-reoxygenation injury through induction of autophagy. Eur $J$ Pharmacol., vol. 776, no., pp. 90-98.

70. Li F., Zong J., Zhang H., Zhang P., Xu L., Liang K., et al. (2017). Orientin reduces myocardial infarction size via eNOS/NO signaling and thus mitigates adverse cardiac remodeling. Front Pharmacol., vol. 8, no., pp. 926.

71. Liu Z.H., Li Q., Chang S., Yang Z.Y., Han N., Yin J. (2016). Protective effect of hexahydrobenzo[c] phenanthridine alkaloids isolated from Corydalis ambigua var. amurensis on myocardial ischemiahypoxia cells. Phytochemistry Letters, vol. 17, pp. 258-262.

72. Lei Q.S., Zuo Y.H., Lai C.Z., Luo J.F., Pang S.W., Zhou H., et al. (2017). New C-21 steroidal glycosides from the roots of Cynanchum stauntonii and their protective effects on hypoxia/reoxygenation induced cardiomyocyte injury. Chinese Chemical Letters, vol. 28, no. 8, pp. 1716-1722.

73. Ming D., Songyan L., Yawen C., Na Z., Jing M., Zhaowen X., et al. (2017). trans-polydatin protects the mouse heart against ischemia/reperfusion 
injury via inhibition of the renin-angiotensin system (RAS) and Rho kinase (ROCK) activity. Food Funct., vol. 8, no. 6, pp. 2309-2321.

74. Wang Y., Wang Q., Zhang L., Ke Z., Zhao Y., Wang D., et al. (2017). Coptisine protects cardiomyocyte against hypoxia/reoxygenation-induced damage via inhibition of autophagy. Biochem Biophys Res Commun., vol. 490, no. 2, pp. 231-238.

75. Zhang M., Zhao Z., Shen M., Zhang Y., Duan J., Guo Y., et al. (2017). Polydatin protects cardiomyocytes against myocardial infarction injury by activating Sirt3. Biochim Biophys Acta Mol Basis Dis., vol. 1863, no. 8, pp. 1962-1972.

76. Zhao X., Zhang F., Wang Y. (2017). Proteomic analysis reveals Xuesaitong injection attenuates myocardial ischemia/reperfusion injury by elevating pyruvate dehydrogenase-mediated aerobic metabolism. Mol Biosyst., vol. 13, no. 8, pp. 15041511.

77. Fu S., Chen L., Wu Y., Tang Y., Tang L., Zhong Y., et al. (2018). Gastrodin pretreatment alleviates myocardial ischemia/reperfusion injury through promoting autophagic flux. Biochem Biophys Res Commun., vol. 503, no. 4, pp. 2421-2428.

78. Li G., Xing X.Y., Luo Y., Deng X.H., Lu S., Tang S.M., et al. (2018). Notoginsenoside R-1 prevents H9c2 cardiomyocytes apoptosis against hypoxia/reoxygenation via the ERs/PI3K/Akt pathway. Rsc Advances, vol. 8, no. 25, pp. 13871-13878.

79. Liu Z., Yang L., Huang J., Xu P., Zhang Z., Yin D., et al. (2018). Luteoloside attenuates anoxia/ reoxygenation-induced cardiomyocytes injury via mitochondrial pathway mediated by 14-3-3eta protein. Phytother Res., vol. 32, no. 6, pp. 1126-1134.

80. Pan H., Zhu L. (2018). Angelica sinensis polysaccharide protects rat cardiomyocytes $\mathrm{H} 9 \mathrm{c} 2$ from hypoxia-induced injury by down-regulation of microRNA-22. Biomed Pharmacother., vol. 106, pp. 225-231.

81. Shou X.L., Zhou R.F., Zhu L.Y., Ren A.H., Wang L., Wang Y., et al. (2018). Emodin, A Chinese Herbal Medicine, Inhibits Reoxygenation-Induced Injury in Cultured Human Aortic Endothelial Cells by Regulating the Peroxisome ProliferatorActivated Receptor-gamma (PPAR-gamma) and Endothelial Nitric Oxide Synthase (eNOS) Signaling Pathway. Medical Science Monitor, vol. 24, pp. 643-651.

82. Sundaram R.L., Sali V.K., Vasanthi H.R. (2018). Protective effect of rutin isolated from Spermococe hispida against cobalt chloride-induced hy- poxic injury in H9c2 cells by inhibiting oxidative stress and inducing apoptosis. Phytomed., vol. 51, pp. 196-204.

83. Wang G., Dai G.L., Song J., Zhu M.M., Liu Y., Hou X.F., et al. (2018). Lactone component from Ligusticum chuanxiong alleviates myocardial ischemia injury through inhibiting autophagy. Frontiers in Pharmacology, vol. 9, 301.

84. Zhang H.J., Chen R.C., Sun G.B., Yang L.P., Zhu Y.D., Xu X.D., et al. (2018). Protective effects of total flavonoids from Clinopodium chinense (Benth.) O. Ktze on myocardial injury in vivo and in vitro via regulation of Akt/Nrf2/HO-1 pathway. Phytomed., vol. 40 , pp. 88-97.

85. Nan J., Nan C., Ye J., Qian L., Geng Y., Xing D., et al. (2019). EGCG protects cardiomyocytes against hypoxia-reperfusion injury through inhibition of OMA1 activation. $J$ Cell Sci., vol. 132, no. 2, pii. jes220871.

86. Yu Y., Xing N., Xu X., Zhu Y., Wang S., Sun G., et al. (2019). Tournefolic acid B, derived from Clinopodium chinense (Benth.) Kuntze, protects against myocardial ischemia/reperfusion injury by inhibiting endoplasmic reticulum stress-regulated apoptosis via PI3K/AKT pathways. Phytomed., vol. 52, no., pp. 178-186.

87. Uttara B., Singh A.V., Zamboni P., Mahajan R.T. (2009). Oxidative stress and neurodegenerative diseases: a review of upstream and downstream antioxidant therapeutic options. Curr Neuropharmacol., vol. 7, no. 1, pp. 65-74.

88. Caverzan A., Casassola A., Brammer S.P. (2016). Reactive oxygen species and antioxidant enzymes involved in plant tolerance to stress, Abiotic and biotic stress in plants-recent advances and future perspectives. InTech.

89. Neri M., Riezzo I., Pascale N., Pomara C., Turillazzi E. (2017). Ischemia/reperfusion injury following acute myocardial infarction: a critical issue for clinicians and forensic pathologists. Mediators Inflamm., vol. 2017, 7018393.

90. Kleinbongard P., Heusch G., Schulz R. (2010). TNF $\alpha$ in atherosclerosis, myocardial ischemia/reperfusion and heart failure. Pharmacology \& therapeutics, vol. 127, no. 3, pp. 295-314.

91. Millar T.M., Phan V., Tibbles L.A. (2007). ROS generation in endothelial hypoxia and reoxygenation stimulates MAP kinase signaling and kinase-dependent neutrophil recruitment. Free Radic Biol Med., vol. 42, no. 8, pp. 11651177. 
92. Omran M.M., Zahran F.M., Kadry M., Belal A.A.M., Emran T.M. (2018). Role of myeloperoxidase in early diagnosis of acute myocardial infarction in patients admitted with chest pain. J Immunoassay Immunochem., vol. 39, no. 3, pp. 337-347.

93. Semenza G.L. (2012). Hypoxia-inducible factors in physiology and medicine. Cell, vol. 148, no. 3, pp. 399-408.

94. Lee S.H., Wolf P.L., Escudero R., Deutsch R., Jamieson S.W., Thistlethwaite P.A. (2000). Early expression of angiogenesis factors in acute myocardial ischemia and infarction. N Engl J Med., vol. 342, no. 9, pp. 626-633.

95. Carmeliet P., Dor Y., Herbert J.-M., Fukumura D., Brusselmans K., Dewerchin M., et al. (1998). Role of HIF-1 $\alpha$ in hypoxia-mediated apoptosis, cell proliferation and tumour angiogenesis. $\mathrm{Na}$ - ture, vol. 394, no. 6692, pp. 485.

96. Wang Z.G., Wang Y., Huang Y., Lu Q., Zheng L., Hu D., et al. (2015). bFGF regulates autophagy and ubiquitinated protein accumulation induced by myocardial ischemia/reperfusion via the activation of the PI3K/Akt/mTOR pathway. Sci. Rep., vol. 5, pp. 9287.

97. El-Magd M.A., Abdo W.S., El-Maddaway M., Nasr N.M., Gaber R.A., El-Shetry E.S., et al. (2017). High doses of S-methylcysteine cause hypoxia-induced cardiomyocyte apoptosis accompanied by engulfment of mitochondaria by nucleus. Biomed. Pharmacother., vol. 94, pp. 589-597. 